Beyond Philology No. 17/4, 2020

ISSN 1732-1220, eISSN 2451-1498

https://doi.org/10.26881/bp.2020.4.06

\title{
COVID-19: The assessment of the current situation, recommendations, challenges, and conduct guidelines for medical interpreters at the time of the SARS-CoV-2 pandemic
}

\author{
ARKADIUSZ BADZIŃSKI
}

Received 30.11.2020,

received in revised form 28.12.2020,

accepted 29.12.2020.

\begin{abstract}
The paper addresses the underlying complexities and phenomena arising in response to the ongoing COVID-19 outbreak, and pertaining to interpreting. The pandemic-related neologisms are introduced, followed by practical guidelines for medical interpreters and the assessment of the problems and challenges encountered in the current mode of work, including (remote) community interpreting. The impact of the pandemic on medical interpreters is also discussed with the associated problems which are also related to the wellbeing of the interpreters themselves at the time of the SARS-CoV-2 pandemic. To fully comprehend the real value of services provided by medical interpreters, it is necessary to assess the health outcomes and the quality of life of patients in longitudinal studies conducted on large cohorts of patients, with particular attention to at least several months of follow-up.
\end{abstract}




\title{
Key words
}

COVID-19, SARS-CoV-2, medical interpreting, community medical interpreting, medical interpreter

\section{COVID-19: Ocena aktualnej sytuacji, zalecenia, wyzwania i wytyczne w zakresie postępowania dla tłumaczy ustnych medycznych w czasie pandemii SARS-CoV-2}

\begin{abstract}
Abstrakt
$\mathrm{W}$ artykule omówiono zjawiska związane $\mathrm{z}$ tłumaczeniem ustnym $\mathrm{w}$ dobie COVID-19. Przedstawiono neologizmy zwiazane $z$ pandemia, praktyczne wskazówki dla tłumaczy medycznych ustnych oraz ocenę problemów i wyzwań, jakie napotykają obecnie, w tym również w tłumaczeniu środowiskowym. Omówiono wpływ pandemii na tłumaczy medycznych i zwiazane $z$ tym problemy, które również dotyczą dobrostanu samych tłumaczy w czasie pandemii SARS-CoV-2. Aby w pełni zrozumieć rzeczywista wartość usług świadczonych przez tłumaczy, należy poddać ocenie wyniki zdrowotne oraz jakość życia pacjentów $\mathrm{w}$ badaniach longitudinalnych przeprowadzonych na dużych kohortach pacjentów, ze szczególnym uwzględnieniem co najmniej kilkumiesięcznego okresu obserwacji.
\end{abstract}

\section{Słowa kluczowe}

COVID-19, SARS-CoV-2, tłumaczenie ustne medyczne, medyczne tłumaczenie środowiskowe, tłumacz ustny medyczny

Access to translation and interpreting in public settings is a natural, human right to be guaranteed. Failure to enforce it may endanger the life and the well-being of millions of people while perpetuating a social landscape where everyone is not equal. (European Commission 2011:21) 


\section{Introduction}

In November 2019, the city of Wuhan, China, caught the attention of the world due to an increasing number of infections and subsequent deaths related to a novel coronavirus medically termed Severe Acute Respiratory Syndrome Coronavirus 2 (SARS-CoV-2), which spread at such a rapid rate that it finally resulted in a global paralysis of the healthcare system. As a result, the World Health Organization (WHO) announced the pandemic on $11^{\text {th }}$ March 2020 (Aslani 2020; WHO 2020a, WHO 2020b).

So far, SARS-CoV-2 infections have been confirmed in 224 countries and territories. Such a sudden outbreak of the pandemic of this magnitude that has already taken the lives of over $1,520,000$ individuals and affected almost 66 million people worldwide has rarely been observed (data as of 30th Nov 2020; according to public WHO announcements). The situation has posed a challenge to people in many respects, including private and professional spheres. A large number of professionals, such as healthcare workers, were initially literally overwhelmed and exhausted due to never-ending duties, let alone the enormous virus-related death risk.

In a mere few months, COVID-19 has fundamentally changed the manner of living. Prolonged stress, uncertainty related to the future and associated mortality rates, and grief over those who passed away have led to clinically significant psychological signs and symptoms, including depression (Stein 2020), increased levels of fear (Lin 2020), anxiety (Wang and Zhao 2020), hopelessness (Shaw 2020), and adjustment disorders (Zhang et al. 2020).

Against this background, prolonged exposure to a completely unknown phenomenon requires rapid response from many different organizations and individuals. Next to healthcare professionals, translators and interpreters, both of whom work under enormous public pressure, are also directly affected, mostly through pressures on time and the need to deliver detailed 
information to the parties concerned accurately and effectively under unprecedented circumstances.

Since the COVID-19 pandemic occurred within a short period of time, the term COVID-19 has become the synonym for the transfer of pandemic-related information and research in professional medical literature published in English and other languages, thereby resulting in the dissemination of information worldwide to both experts and non-experts, which is done mostly by translators and interpreters.

\section{COVID-19-related neologisms}

Each phenomenon of crucial importance leaves an imprint not only on certain aspects of the geopolitical or socio-economic situation but also in the language itself since it is the language that allows individuals to express certain states, emotions and other situations and this has been observed in the current SARS-CoV-2 pandemic, with COVID-19 neologisms being typical examples.

Language is certainly a vital part of the response to COVID19 as illustrated by the instance of England that faced legal proceedings due to the fact that a British sign language interpreter was not included in its regular government briefings as opposed to Scotland, Wales, and Northern Ireland (as reported by the BBC on 28th April 2020).

The language of medicine is related to an unstoppable progression of neologism formation, one of the reasons being the occurrence of new disease entities or emerging infectious diseases (e.g., Escherichia coli O157:H7, hantavirus), technologyrelated terms connected with new modalities, particularly in neuroimaging studies (mMRI, fMRI), newly created specialties (e.g. nanotechnology, hypertensiology) and other phenomena related to pharmacotherapy (e.g. polypharmacy). The English language is currently the lingua franca in medicine and therefore dictates certain trends for the adoption of terminological lexemes (Badziński 2018). Neologisms play a crucial role since they designate new concepts. However, they may have simultane- 
ously more than one designation, which is related to the fact that they have a cognitive as well as communicative dimension that definitely determines the use of such neologisms in medical discourse (Haddad Haddad and Montero-Martínez 2020). As indicated by Cabré Castellvi (1999), coining neologisms has to be conducted in accordance with the linguistic language code in which they are created.

At the time of the COVID-19 pandemic, the necessity to fill in terminological gaps is of paramount importance so that scientific information could be disseminated worldwide. Additionally, the process in question should bridge the communication between experts and non-experts (laypersons). To achieve this aim, adequate terms must be coined.

According to Thorne (2020), the number of lexical items created during the pandemic in both non-specialized areas and technical terminology has reached more than 1,000 new words. From a linguistic and translational perspective, the timeline of the COVID-19 pandemic has shown that the WHO has referred to the disease using at least several terminological compounds. It was initially termed pneumonia of unknown cause and later novel coronavirus. Furthermore, the WHO initially adopted the acronyms (e.g. $n \mathrm{Cov}$ ), and abbreviations or short forms (2019$n \mathrm{CoV}$ ) and finally opted for the term Coronavirus Disease 2019 and its current acronym COVID-19. The underlying intention was to use an unambiguous and mono-referential term, without any geographical or human indications, so avoiding both inaccuracy and stigmatization. The officially adopted term (Coronavirus Disease 2019) is composed of 3 lexemes that refer to the type of virus responsible for the disease, the disease process, and the year of the outbreak. The term used to refer to the type of virus causing the disease is the compound lexeme coronavirus.

As reported by Kenyon (2020), Yong (2020), Furukawa et al. (2020), other terms have also been coined by the WHO, whereas other neologisms have been proposed by the Centers for Disease Control and Prevention (CDC) - (1) medical terms with a new sense (field hospital; super-spreader, frontline healthcare 
worker, frontliner), (2) entirely new headword entries (drive-thru testing, personal protective equipment, N95 R referred to as an 'N95 mask', ambulatory triage algorithm, covexit, coronacoma, anticoronavirus, covidials, COVID toes, triaged, convalescent plasma, emergency use authorization), and (3) new sub-entries (i.e., compounds or phrases integrated into the body of newly or recently updated entries; e.g., case fatality ratio, cytokine storm, $\mathrm{R}$ number, spike protein).

The COVID-19 pandemic has influenced the terminology and thus translation since a plethora of newly formed terms have been introduced to the language.

Within days following the onset of the pandemic, translators and interpreters faced the challenge of providing accurate information for healthcare providers as well as laypersons worldwide. Since misinformation can cause inevitable damage, professionals in these disciplines work closely with public authorities and healthcare providers to enable proper dissemination of information. To illustrate, as indicated by the official website of the Ministry of Health of New Zealand, interpreters and translators were involved in the process of translating official documentation for the ministry in multiple languages to provide knowledge to citizens of different origin (including such languages as Māori, Arabic, French, German, Indonesian or Thai). In the USA, President Trump's administration was involved in translating medical data for the Spanish community in the US territory. According to Runcieman (2020: 6), in the medical settings, "there would appear at first to be a tendency for the interpreter to act more as a conduit, particularly when communicating the medical practitioner's directives regarding medicines and curative therapies".

To the best of the author's knowledge, there have been no official reports on the number of COVID-19-related medical translation and interpreting services as yet. Based on the literature review, there have been no specific data that address this issue in a detailed manner with the division into countries or regions and hence the collection of such vital information in this respect is of utmost importance. However, some residual 
information can be obtained. For instance, the Royal Melbourne Hospital, Australia, reported an increase in video interpreting appointments (approximately 20 appointments monthly before the pandemic to over 220 at the time of the pandemic; data obtained by the author via telephone consultation).

\section{Challenges of medical interpreting at the time of the pandemic}

The outbreak of the COVID-19 pandemic resulted in certain changes in the field of translation and interpreting, mainly in terms of the aspects related to the reorganization of work. The translation/interpreting industry was also affected by certain restrictions and changes. However, it is mainly interpreting that faces new challenges now. Despite the fact that most scheduled conferences and meetings were either cancelled or postponed, Internet platforms facilitated the provision of conference interpreting services. Therefore, the significance of platform solutions is not to be underestimated.

Indeed, interpreters have to bear in mind the prospect of unforeseen difficulties, including quality problems (loss of connection; equipment failure that cannot be eliminated in a rapid manner). Additionally, legal issues should also be mentioned in this respect, especially in the case of unauthorized access to sound or image that is broadcast during the process of interpreting (risk of hacking, unauthorized recording). The responsibility in this respect should be exclusively on the side of the organizing body calling the meeting, which is not always stipulated in contracts the interpreters are provided with.

Another challenge is related to the work itself as interpreters work from booths. Under current circumstances, they are in two different places and mutual exchange between them is considerably limited (if possible).

Last but not least, the current situation has had a significant impact on the psychological well-being of interpreters. Prior to the pandemic, they were involved in the delivery of information, whereas at the present moment they are also involved in 
preparing the technical equipment and self-management of problems they have never experienced before (sudden Internet disconnection, freezing). Working under extreme pressure, often single-handedly and in different time zones may take its toll on the health of interpreters.

Since a significant number of meetings and conferences are currently being held online via different platforms, the demand for professional medical interpretation has shifted to another domain known as remote simultaneous interpreting, also known as distance interpreting. As a result, a dramatic increase in the number of medical conferences during which simultaneous interpretation services are being used has been observed at the time of the pandemic (data collected over the phone from the WHO headquarters, Geneva and limited to Europe only). Therefore, the need for medical interpreters has been reported. However, due to social distancing and measures for infection control, these specialists often work over the phone or via teleconference. Interestingly, despite the fact that the global economic slowdown has resulted in a decreased number of translations due to the lockdown, a significantly higher demand has been observed in the field of medicine.

Currently, medical interpreters work remotely, which results in the multiplication of challenges for front-line doctors on the one hand and non-English-speaking patients on the other. Due to the fact that personal protective equipment is in short supply at hospital settings across Poland, only some clinical interpreters are physically able to work in person with COVID-19 patients as they normally would. As a result, most language interpretation is then performed remotely. Obviously, under these circumstances, communicating information through an interpreter may even triple the length of an exchange of knowledge, and add confusion and anxiety to the conditions that are already stressful for patients and their loved ones. Additionally, the codes of practice followed in the care of COVID-19 patients (i.e., the unusually rapid pace at which medical assessment is made, the desire of healthcare professionals to limit the duration of their exposure to patients) further exacerbate the 
problem, thus creating numerous obstacles to effective interpretation.

In many countries (e.g., United States, United Kingdom), separate recommendations have been issued for interpreters that stipulate guidance on health and safety in terms of working practices in medical settings during the SARS-CoV-2 pandemic. At the same time, it should be noted that rules and regulations issued by the WHO must be adhered to at all times and must always take priority, irrespective of the guidelines given elsewhere. As reported by Runcieman (2020), in 2004, America's National Council on Interpreting in Health Care (NCIHC) issued the National Code of Ethics for Interpreters which stressed the role of the interpreter as an 'advocate' rather than a linguistic conduit for patients when their health and well-being are at risk, the interpreter may be then justified to act as an advocate, which, in this context, is understood to be the act of undertaking, on behalf of a person, an assignment that exceeds the frames of facilitating communication with the intention of supporting good health outcomes. Although the guidelines given by the Association of Sign Language Interpreters (2020) were specifically prepared for sign language interpreters in medical settings, they can also be successfully and practically applied to other medical interpreters (both in terms of simultaneous and consecutive modes) and therefore some of them were incorporated in the present paper.

As the primary aim of the interpreter is the impartial performing of interpreting undertaking so as to realize the communication goals of the parties involved in the interaction, the effects of misinterpretation could have grave immediate sequelae for patients. Of note, the process of interpreting may be significantly affected by a number of variables, such as physical and mental strain related to the wearing of protective equipment.

Interpreters should be treated like healthcare workers rather than members of the public. General health and safety policies for healthcare specialists should be simultaneously applied to interpreters working in medical settings. Interpreters ought to be provided with the same personal protective equipment (PPE) 
which medical personnel use in the setting when exposed to the same level of risk. If interpreters attend more than one assignment on the same premises, yet at different wards/departments, a separate single-use PPE must be provided as in the case of health professionals. The same regulation is applicable to masks, although they conceal mouth movements, considerably impairing the interpreting process (face shields may be an alternative measure).

It is of paramount importance that all parties involved in interpreting (patients, health professionals, and interpreters) cooperate to work out the best solution for each individual (as in the algorithm for personalized medicine).

Medical interpreting at the time of the COVID-19 pandemic can be mostly performed face-to-face in situ or remotely. The former is related to a situation when the interpreter provides their service at a distance of several meters or through glass due to the potential infection risk. The latter is related to remote interpreting, which is considered a beneficial option that minimizes the infection risk for all parties involved when applied in routine appointments that do not require obtaining an extensive history, but repeat prescriptions, referrals or copies of official documents. However, remote interpreting is discouraged in the case of mental health assessment, terminally ill patients on oxygen therapy or those whose movements are restricted (due to medical equipment, both pre- and post-operative consultations), or those under the influence of illicit substances, as they may severely impair both language production and comprehension except for situations when there is no other alternative (e.g. emergency cases or when a healthcare professional agrees due to the benefit-risk-ratio of in situ interpreting). Therefore, the decision of how to undertake the interpretation should always be made in agreement with all parties involved (i.e., the patient, the medical health provider, and the interpreter). In turn, remote options are still better than none in an emergency or when no in situ face-to-face interpreting is available.

Another issue is related to interpreting in departments of geriatric medicine where an increased infection rate has been 
reported since the onset of the pandemic (also in Poland). Such patients may encounter additional stressful challenges connected with using remote interpreting services and display idiosyncratic language use due to comorbidities (e.g., conductive, sensorineural or special hearing loss, non-syndromic deafness, auditory processing disorder), assistive devices (cochlear implants) and the lack of experience in using such services. Furthermore, mental health settings, particularly restricted access departments / wards, present additional challenges for interpreters since social distancing measures may be difficult to enforce.

The coronavirus outbreak has indeed multiplied the logistical barriers for delivering medical interpretation (hospital rooms filled with buzzing equipment that delivers oxygen at 10-15 litres per minute). Interpreters have to use their words more sparingly, which is detrimental to their work, partly due to the fact that not only the quality of work suffers at the time of such remote contact instead of in person.

Interpreters working in medical settings must also take care of their own comfort and well-being, bearing in mind that the quality of interpretation is reduced after approximately 20-30 minutes of continuous work with no break in situ, as indicated by studies (Moser-Mercer et al. 1998), or remotely (Moser-Mercer 2005). Therefore, they should unquestionably limit working or discontinue practising if their ability to practise could be adversely affected by their mental or physical well-being. Bearing in mind their own safety, interpreters, who must always act in the best interests of individuals and work only within the limits of their expertise, ought to only accept assignments in a highrisk COVID-19-related environment if they consider it necessary and no other option of providing support in the form of interpreting is possible. Consequently, any interpreter with COVID19 symptoms still working in high-risk settings can themselves risk breaching legal codes of conduct, which can result in legal sanctions against them (cf. The Association of Sign Language Interpreters 2020).

It is of crucial importance to bear in mind that under no circumstances should relatives, especially children, be used as 
interpreters. The involvement of family members is absolutely contraindicated and unethical (even if they are professional interpreters themselves) due to their lack of impartiality. Additionally, the strain on relatives who are neither trained nor emotionally impartial can significantly impact the patient's mental health, thus adversely affecting future mutual relationships.

\section{The main interpreting-related problems during COVID-19 as reported by medical interpreters}

The author of the present paper is a medical translator and interpreter himself who has been involved in the process of providing services to over 14 medical centres across Poland. These services were mainly related to consultations before emergency procedures, such as surgery, neuroinvasive procedures, and (non)invasive diagnostic modalities (including imaging studies) where patients must be provided not only with written informed consent but also a detailed procedure-related knowledge. Most of the consultations were done over the phone (tele-interpreting services), which was particularly challenging due to the fact that most of the activities were performed practically in a consecutive mode, which resulted in the lengthening of the whole diagnostic process. However, in cases where the presence of the interpreter was necessary, the interpreter delivered the services on the premises (i.e., mostly in hospital settings).

For the purposes of the present paper, the author contacted three other interpreters who were also involved in delivering assistance in the medical field. The following are the most common problems that were encountered in the process of interpreting by the author of the paper: technical (connection) problems, time pressure (before emergency surgery), stress related to the lack of another interpreter to provide assistance, risk of being infected by a patient, risk of transmitting infection to a patient, involvement of family members in the process of interpreting, factors that impaired patient's language skills (e.g. a history of stroke or other comorbidities affecting effective communication), 
too lengthy/short descriptions provided by medical healthcare workers. Other items indicated by the three interpreters also included anxiety/fear of patients that can result in providing incoherent information, complex history (from several departments), and patients with additional needs (deafness), mental and physical exhaustion due to the length of interpreting, no feedback from medical personnel, stress due to unpredictability of the subject matter of interpreting, too specialized terms given by the medical personnel (necessity to paraphrase specialized terminology to patients), unknown terminology, impatience on both sides (medical personnel and a patient).

The above factors resulted in significant delays in interpreting, which was frequently related to the necessity of repeating the questions and asking for clarification, or even rephrasing in the case when the physician(s) asked the question in a highly specialised medical register or jargon that was completely incomprehensible to the patient.

What needs to be considered is related to the cognitive processes that occur during interpreting (Tymoszuk 2016). Since some fragments were interpreted also in situ and in the simultaneous mode, the effort model by Daniel Gile should also be taken into account. According to the model, the act of interpreting requires a certain amount of mental energy that is in fact available in limited supply. Interpretation "takes up almost all of this mental energy, and sometimes requires more than is available, at which times performance deteriorates" (Gile 1995: 161), which may account for the interpreter's comments on mental fatigue or even exhaustion (cf. Braun and Taylor 2012). Although Tymoszuk (2016) in her monograph refers to the simultaneous mode, her comments can be also related to the consecutive mode or remote community interpreting when she observes that interpreter isolation is related to the lack of feedback in the form of non-verbal reactions, which is also a source of information for an interpreter and is absent when interpretation is conducted over the phone. 


\section{Further issues to consider}

The ultrarapid transition in terms of service delivery necessitated by COVID-19 has provided some opportunity for a systemic change regarding professional interpreting services. Firstly, the effectiveness of such services should be adequately assessed. All healthcare centres that currently provide services to people with (highly) limited English proficiency ought to adopt appropriate remote interpreting services. Moreover, the number of health services using remote interpreting should be assessed, measured, registered and reported to show the magnitude of the phenomenon. Furthermore, it is crucial to explore the barriers associated with remote interpreting services that hamper communication and then address them to prevent their occurrence in the future. Satisfaction of all parties should be also addressed (physician-patient-interpreter), bearing in mind the wellbeing of all parties involved in the process of transferring knowledge. From the economic perspective, the cost of remote delivery should be evaluated (comparison of costs between different modes, e.g., video versus telephone) to work out a generally acceptable and economically feasible policy.

Last but not least, to comprehend the tangible value of services offered by medical interpreters, both health outcomes and the quality of life of patients should (and must) be assessed in longitudinal studies conducted on large cohorts of patients with particular attention to at least several months of follow-up.

\section{Study limitations}

The pandemic is characterized by an unpredictable course and hence some of the recommendations provided in this paper may be subject to partial change in the future. The recommendations stipulated in the present manuscript are based on the algorithms that have been developed outside of Poland and do not constitute a finite spectrum of guidelines due to the pace of the pandemic. The problematic issues reported may serve as a pilot study and, at the same time, may be a stimulus for conducting 
further research into detrimental factors affecting medical interpreting and proposing new algorithms of management and procedure.

\section{Conclusions}

The role of medical interpreters has definitely been given a new scope. Such specialists are not only immersed in the new workrelated surroundings but have to be fully aware of certain riskrelated activities connected with performing the duties (the risk of cross-infection). Bearing in mind the above, different procedures related to interpreting services also come into play, let alone the COVID-19-related neologisms. Due to the immense impact of the pandemic, some of the COVID-19 lexemes will be probably never lost in translation and will certainly have their well-established place in the language of medicine and language in general. It is, however, tentative to predict to what extent all associated lexemes will remain in a given language. However, considering a poor prognosis related to the virus control, it seems that the medical terms coined due to the COVID-19 situation in English and Polish will remain for years to come. Therefore, further studies are warranted on the use of Polish equivalents related to the COVID-19 disease. Bearing in mind the interpreter's code of conduct (confidentiality and impartiality) which must be maintained at all times, the decision whether to conduct in situ interpreting should also be always done with due regard for individuals suspected of or adversely affected by the COVID-19 pandemic and consideration of one's own wellbeing. Furthermore, the decision should be based on the algorithm of the case-by-case basis, considering the benefit-risk ratio of such decisions which should be made jointly by the medical and interpreting professionals. 


\section{References}

Aslani, Parisa (2020). "What are our health expectations in a pandemic?". Health Expectations 23/2: 257-258.

Badziński, Arkadiusz (2018). "Collocations, equivalence and untranslatability as selected critical aspects in medical translation". In: Wioleta Karwacka (ed.). Towards Understanding Medical Translation and Interpreting, Gdańsk: Wydawnictwo Uniwersytetu Gdańskiego, 67-83.

Braun, Sabine, Judith Taylor (2012). "Video-mediated interpreting in criminal proceedings: two European surveys". In: Sabine Braun, Judith Taylor (eds.). Videoconference and Remote Interpreting in Legal Proceedings. Cambridge - Antwerp: Intersentia, 69-98.

Cabré Castellví, Teresa (1999). Terminology: theory, methods and applications. Amsterdam and Philadelphia: John Benjamins.

European Commission (2011). Special Interest Group on Translation and Interpreting for the Public Services: Final report. Brussels: European Commission, Directorate-General for Interpretation.

Furukawa, Nathan, John Brooks, Jeremy Sobel (2020). "Evidence supporting transmission of severe acute respiratory syndrome Coronavirus 2 while presymptomatic or asymptomatic". Emerging Infectious Diseases 26/7: e1-e6

Gile, Daniel (1995). Basic Concepts and Models for Interpreter and Translator Training. Amsterdam - Philadelphia: John Benjamins.

Haddad Haddad, Amal, Silvia Montero-Martinez (2020). "COVID-19: A metaphor-based neologism and its translation into Arabic". JCOM 19 (05), A01: 1-21.

Kenyon, Cynthia (2020). "Flattening-the-curve associated with reduced COVID-19 case fatality rates - an ecological analysis of 65 countries". Journal of Infection 81/1: e98-e99.

Lin, Chung-Ying (2020). "Social reaction toward the 2019 novel coronavirus (COVID-19)". Social Health and Behavior 3/1: 1-2.

Moser-Mercer, Barbara (2005). "Remote interpreting: Issues of multisensory integration in a multilingual task". Meta 50/2: 727-738.

Moser-Mercer, Barbara, Alexander Künzli, Marina Korac (1998). "Prolonged turns in interpreting: Effects on quality, physiological and psychological stress (pilot study)". Interpreting 3/1: 47-64.

Runcieman Alan James (2020). "Community interpreting and the COVID-19 crisis: Present relevancy and future directions". Tilburg Papers in Culture Studies 242: 1-22. 
Shaw, Sebastian (2020). "Hopelessness, helplessness and resilience: The importance of safeguarding our trainees' mental wellbeing during the COVID-19 pandemic". Nurse Education in Practice 44: 1-2.

Stein, Murray (2020). "Editorial: COVID-19 and anxiety and depression in 2020". Depression and Anxiety 37/4: 302-302.

The Association of Sign Language Interpreters (2020). "Guidelines for booking interpreters in healthcare settings during the COVID-19 pandemic". Available at <https://asli.org.uk/wp-content/uploads / 2020/06/Best-Practice-for-Booking-Interpreters-in-Healthcare-set tings-during-Covid-19-FINAL.pdf $>$. Accessed 30.11.2020.

Thorne, Tony (2020). "\#CORONASPEAK - the language of Covid-19 goes viral." Available at <language-and-innovation.com/2020/04 / 15/coronaspeak-part-2-the-language-of-covid-19-goes-viral/>. Accessed 30.11.2020.

Tymoszuk, Katarzyna (2016). Przetwarzanie tekstu $w$ tłumaczeniu symultanicznym. Lublin: Wydawnictwo Uniwersytetu Marii CurieSkłodowskiej.

Wang, Chongying, Hong Zhao (2020). "The impact of COVID-19 on anxiety in Chinese university students". Frontiers in Psychology 11: $1-7$.

World Health Organization (2020a). "Coronavirus disease (COVID-19) advice for the public". Geneva: World Health Organization. Available at <https://www.who.int/emergencies/diseases/novel-coronavirus-2019/advice-for-public >. Accessed 30.11.2020.

World Health Organization (2020b). "Coronavirus disease 2019 (COVID-19) situation report - 56". Geneva: World Health Organization. Available at <https://www.who.int/docs/default-source/co ronaviruse/situation-reports/20200316-sitrep-56-covid-19.pdf?sf vrsn=9fda7db2_6>. Accessed 30.11.2020.

Yong, Ed (2020). "Long-haulers are redefining COVID-19 - Without understanding the lingering illness that some patients experience, we can't understand the pandemic". The Atlantic. Available at $<$ https://www.theatlantic.com/health/archive/2020/08/long-ha ulers-covid-19-recognition-support-groups-symptoms/615382/>. Accessed 30.11. 2020.

Zhang, Wen, Kun Wang, Lu Yin, Wen-feng Zhao, Qing Xue, Mao Peng Bao-quan Min, Qing Tian, Hai-xia Leng, Jia-lin Du, Hong Chang, Yuan Yang, Wei Li, Fang-fang Shangguan, Tian-yi Yan, Hui-qing Dong, Ying Han, Yu-ping Wang, Fiammetta Cosci, Hong-xing Wang (2020). "Mental health and psychosocial problems of medical health 
workers during the COVID-19 epidemic in China". Psychotherapy and Psychosomatics 1: 1-9.

Arkadiusz Badziński

ORCID iD: 0000-0001-7019-6131

University of Silesia in Katowice

Institute of Linguistics

Gen. Stefana Grota-Roweckiego 5

41-205 Sosnowiec

Poland

arkadiusz.badzinski@us.edu.pl 